\title{
Sistem Informasi Persediaan Barang Berbasis Java PT. Andhika Sarana Mitra Jakarta Pusat
}

\author{
Inventory Information System Based On Java PT. \\ Andhika Sarana Mitra Jakarta Pusat
}

\author{
M. Rifqi Tsani \\ Teknik Informatika STMIK YMI TEGAL \\ Jl. Pendidikan No.01 Kota Tegal \\ rifqiaya@gmail.com
}

\begin{abstract}
Abstrak
Pada saat ini, kebutuhan informasi semakin penting dan mendesak sejalan dengan arus perkembangan teknologi yang semakin maju. Banyak perusahaan berskala besar maupun kecil menggunakan komputer untuk mendukung kegiatan dalam perusahaannnya. Komputer serta aplikasi didalamnya pada saat ini bukanlah merupakan sesuatu hal yang baru lagi, hampir seluruh badan usaha yang besar maupun kecil telah menggunakan komputer sebagai salah satu sarana pendukung dalam kegiatan pada perusahaan tersebut. PT Andhika Sarana Mitra Jakarta Pusat merupakan perusahaan swasta yang masih menggunakan sistem manual dalam pengolahan data, terutama pada pengolahan data persediaan barang sehingga memperlambat dalam proses pengolahan data dan pengontrolan persediaan barang. Untuk mengatasi masalah tersebut maka dirancanglah sistem informasi persediaan barang berbasis java. Dalam pembutan sistem informasi persediaan barang berbasis java metode perancangan yang digunakan adalah Unified Modeling Language (UML). dengan aplikasi NetBeans IDE 7.2, SQL Server 2008 untuk perancangan basis datanya. Dengan menggunakan sistem informasi persediaan barang berbasis java ini dapat mempermudah dan mempercepat kinerja bagian gudang serta dapat mengontrol jumlah persediaan barang.
\end{abstract}

Kata Kunci: Sistem Informasi, UML, Java, NetBeans.

\begin{abstract}
At this time, the needs of the more important and urgent information in line with the current development of increasingly advanced technology. Many companies large and small use computers to support activities in perusahaannny. Computers and applications on it at this time is not a new thing anymore, almost all enterprises large and small have been using computers as a means of supporting the activities of the company. PT Andhika Sarana Mitra Central Jakarta is a private company that still use manual system in data processing, especially in the processing of inventory data thus slowing in the data processing and inventory control. To overcome these problems then designed the system inventory information based on java. In pembutan system inventory information java-based design method used is the Unified Modeling Language (UML).by application of NetBeans IDE 7.2, SQL Server 2008 for database design data. Using the system inventory information based on java can facilitate and speed up the performance of the warehouse.
\end{abstract}

Keywords: Information Systems, UML, Java, NetBeans.

\section{PENDAHULUAN}

Kebutuhan informasi semakin penting dan mendesak sejalan dengan arus perkembangan teknologi yang semakin maju. Banyak perusahaan berskala besar maupun kecil menggunakan komputer untuk mendukung kegiatan dalam perusahaannnya. Komputer serta aplikasi didalamnya pada saat ini bukanlah merupakan sesuatu hal yang baru lagi, hampir seluruh badan usaha yang besar maupun kecil telah menggunakan komputer sebagai salah satu 
sarana pendukung dalam kegiatan pada perusahaan tersebut. PT Andhika Sarana Mitra Jakarta Pusat merupakan perusahaan swasta yang masih menggunakan sistem manual dalam pengolahan data, terutama pada pengolahan data persediaan barang sehingga memperlambat dalam proses pengolahan data dan pengontrolan persediaan barang. Pada pembutan sistem informasi ini penulis hanya membahas tentang sistem informasi persediaan barang yang meliputi pengolahan data petugas, data supplier, data barang, transaksi penerimaan barang, pengeluaran barang dan laporan.

Adapun tujuan yang ingin dicapai dalam penelitian ini adalah mempermudah dalam pemrosesan data barang yang masuk dan barang yang keluar dengan cepat dan akurat sehingga dapat menghasilkan informasi sesuai dengan kebutuhan serta membuat suatu program yang dapat melakukan pengontrolan stok barang digudang sehingga dapat memberitahukan jumlah stok barang yang ada digudang dengan cepat dan akurat. Didalam proses pembuatan sistem informasi persediaan barang berbasis java ini menggunakan metode penelitian deskriptif kualitatif dan untuk metode perancangan yang digunakan adalah Unified Modeling Language (UML).dengan aplikasi NetBeans IDE 7.2, SQL Server 2008 untuk perancangan basis datanya. SQL Server 2008 adalah sebuah terobosan baru dari Microsoft dalam bidang database [1]. Setiap proses manual dari perusahan dapat digantikan oleh komputer karena penyediaan informasi yang lebih canggih serta dapat mendukung proses pengambilan keputusan yang dilakukan oleh manajemen [2]. Kebutuhan akan teknologi informasi sangat mendukung kinerja kegiatan yang di lakukan koperasi [3]. Kesuksesan perusahaan dalam mempertahankan bisnisnya tidak terlepas dari peran perusahaan tersebut dalam mengelola persediaan barang sehingga dapat memenuhi permintaan dari pelanggan semaksimal mungkin [4]. penggunaan sistem informasi inventori barang di Bank Sampah Garut dapat mempermudah dan mempercepat pengaksesan data barang, serta mempermudah pembuatan laporan barang masuk dan barang keluar, juga dapat membuat laporan penjualan barang [5]. Pada prinsipnya persediaan mempermudah atau memperlancar jalannya operasi organisasi yang harus dilakukan untuk memproduksi barang-barang yang penyelenggaraan catatan persediaan [6].

\section{METODE PENELITIAN}

Penelitian ini menggunakan metode penelitian deskriptif kualitatif dengan metode studi kasus pada PT Andhika Sarana Mitra Jakarta Pusat. Metode penelitian dalam perancangan sistem ini menggunakan pendekatan berorientasi objek dengan pemodelan Unified Modeling Language (UML). Unified Modeling Language (UML) adalah salah satu alat bantu yang handal di dunia pengembangan system yang berorientasi objek [7]. Tahap penelitian ditujukan pada bagan berikut:

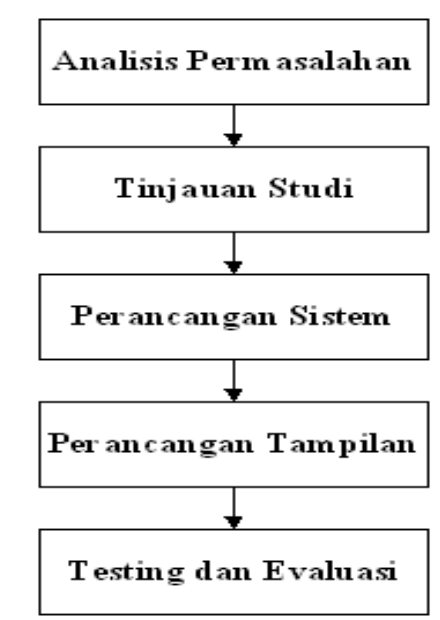

Gambar 1. Tahapan Penelitian 
Pada gambar 1 digambarkan tahapan-tahapan penelitian, terdiri dari tahapan analisis, tinjauan studi dan rancangan sistem. Tahapan analisis terdiri dari analisis terhadap permasalahan, tinjauan studi dilakukan dengan mereview penelitian serupa yang pernah dilakukan oleh peneliti sebelumnya, Pada tahapan rancangan, sistem dirancang dengan pemodelan UML terdiri dari use case diagram dan activity diagram.

\section{HASIL DAN PEMBAHASAN}

\subsection{Proses Bisnis}

PT. Andhika Sarana Mitra adalah perusahaan yang bergerak dibidang perdagangan barang dan jasa. Dalam kegiatan persediaan barang dimulai dari bagian gudang member informasi data barang yang akan dipesan kepada bagian pembelian, bagian pembelian menerima informasi dan membuat PO (purchase order) untuk supplier, kemudian supplier menerima PO (purchase order) dan mengirim barang disertai faktur. Bagian gudang menerima barang dan faktur dan langsung membuat SPB (surat penerimaan barang) untuk supplier yang ditandatangani oleh bagian pembelian. Supplier menerima SPB (surat penerimaan barang) dan langsung konfirmasi pembayaran pada bagian pembelian, bagian pembelian melakukan pembayaran ke supplier. Supplier menerima pembayaran dan langsung membuat kwitansi untuk bagian pembelian. Jika dituangkan dalam Activity Diagram maka proses bisnis awal pada bagian persediaan barang adalah sebagai berikut:

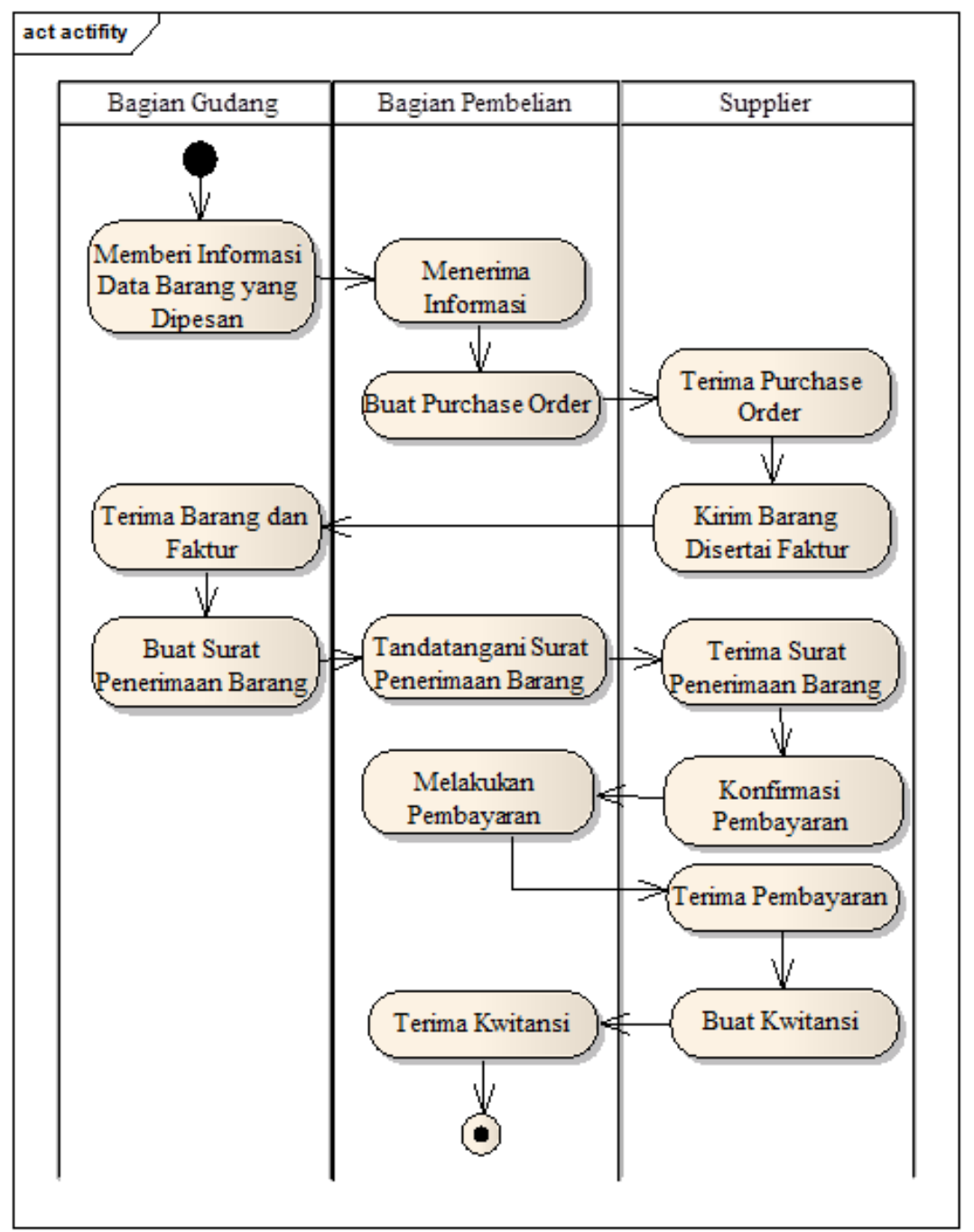

Gambar 2. Activity Diagram Prosedur Persediaan Barang 


\subsection{Rancangan Sistem}

Database dalam perancangan sistem informasi persediaan barang ini sangat penting untuk nyimpan berbagai macam data diantaranya data barang, data supplier dan data transaksi. Jika dituangkan ke dalam Entity Relationship Diagram atau ERD, maka desain awal dari sistem ini adalah seperti gambar berikut:

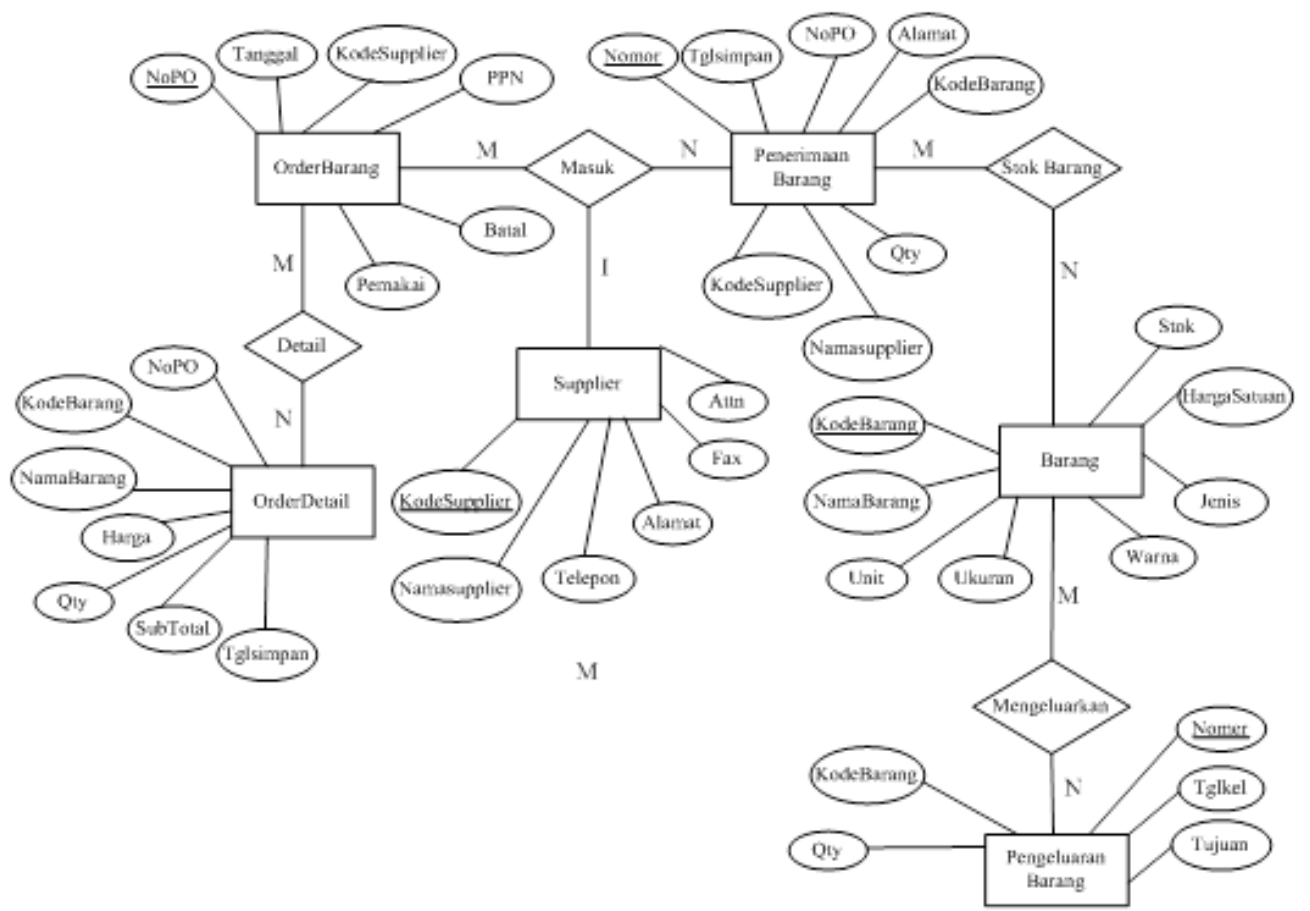

Gambar 3. Entity Relationship Diagram

Pada perancangan sistem informasi persediaan barang berbasis java, penulis menggunakan use case diagram untuk penggambaran sistem dari sudut pandang pengguna sistem tersebut (user). Berikut adalah use case diagram dari sistem informasi persediaan barang:

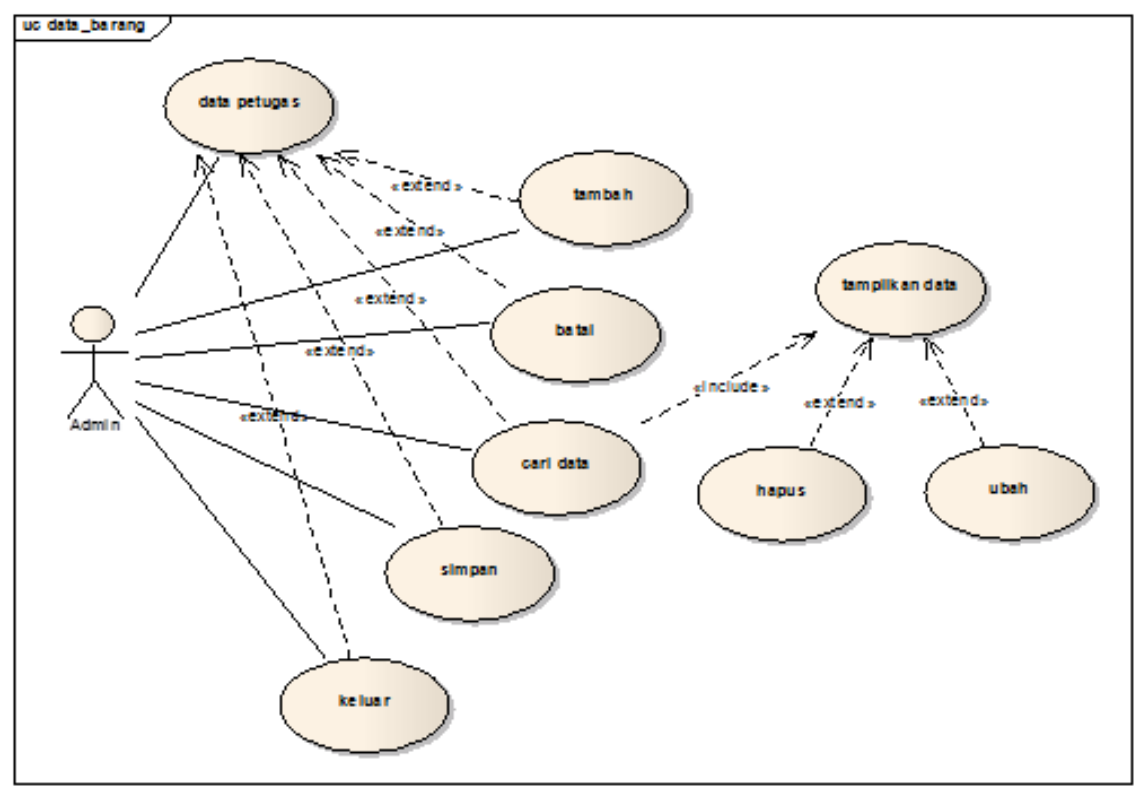

Gambar 4. Use Case Diagram Mengelola Data Petugas 


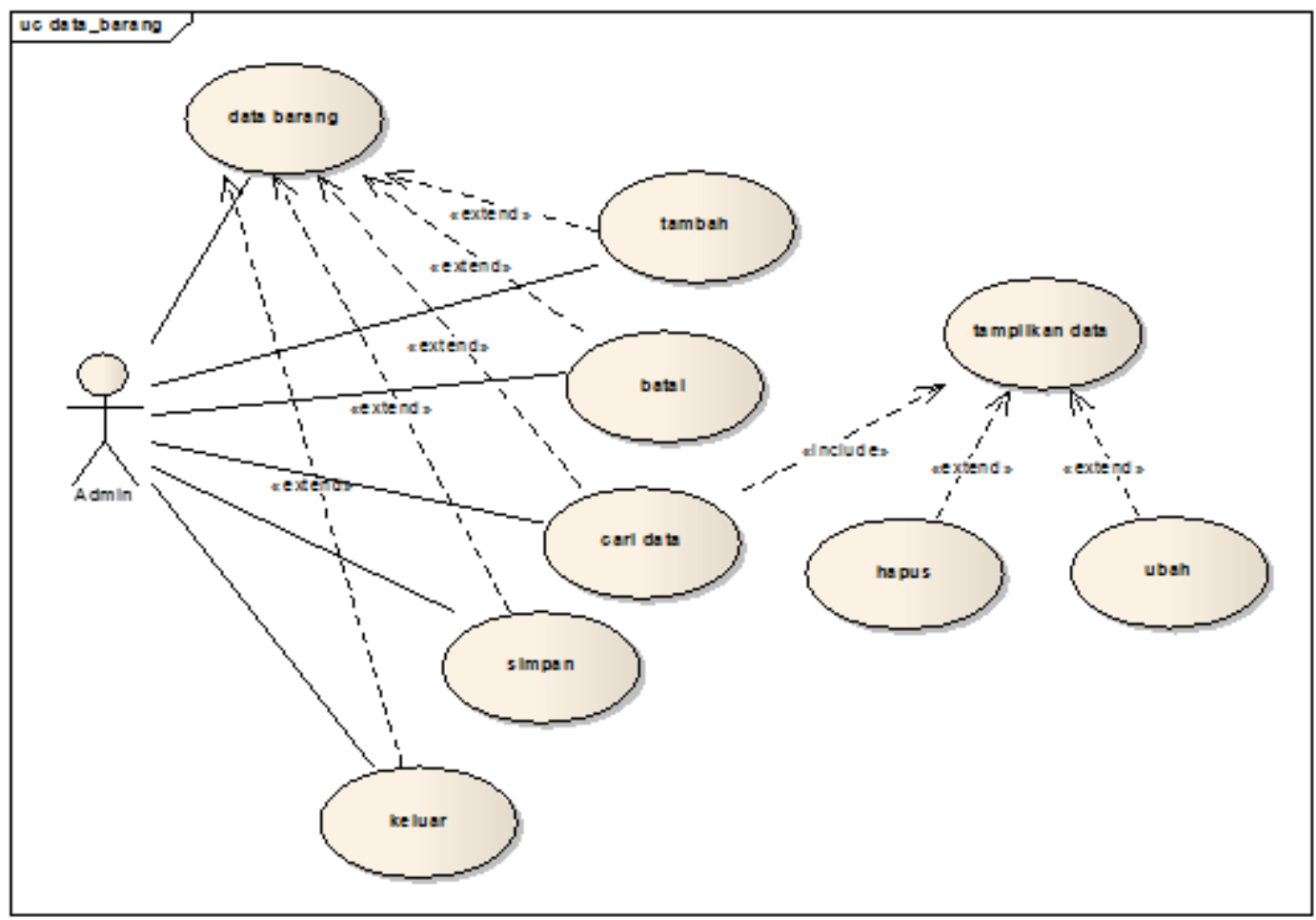

Gambar 5. Use Case Diagram Mengelola Data Barang

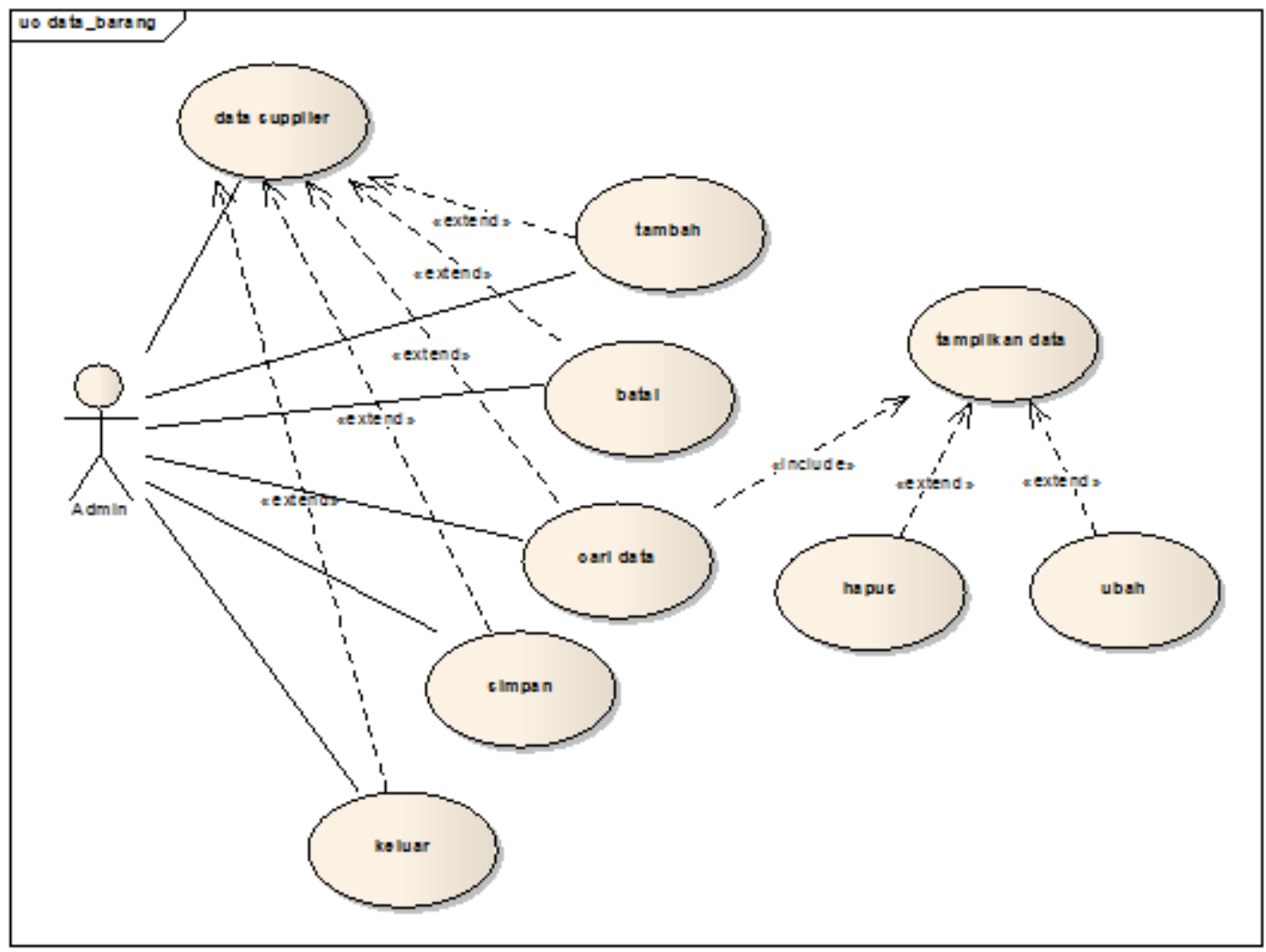

Gambar 6. Use Case Diagram Mengelola Supplier 


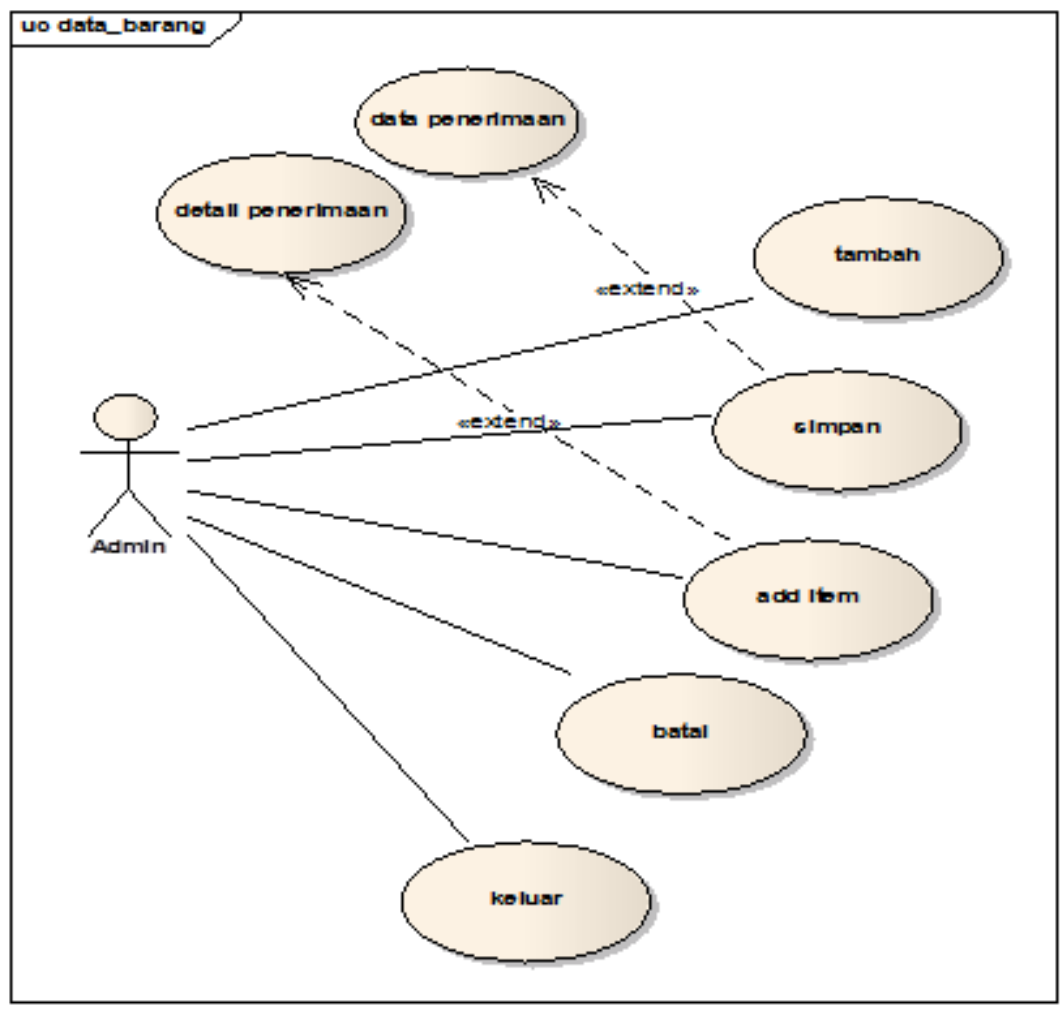

Gambar 7. Use Case Diagram Penerimaan Barang

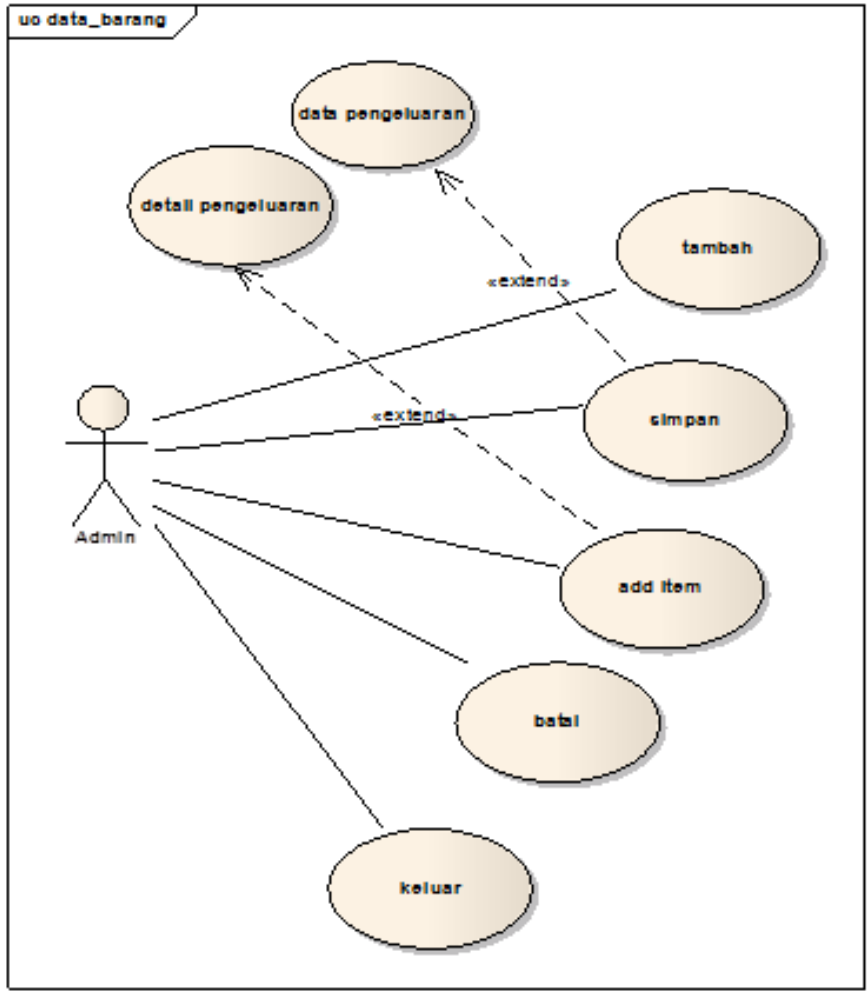

Gambar 8. Use Case Diagram Pengeluaran Barang 


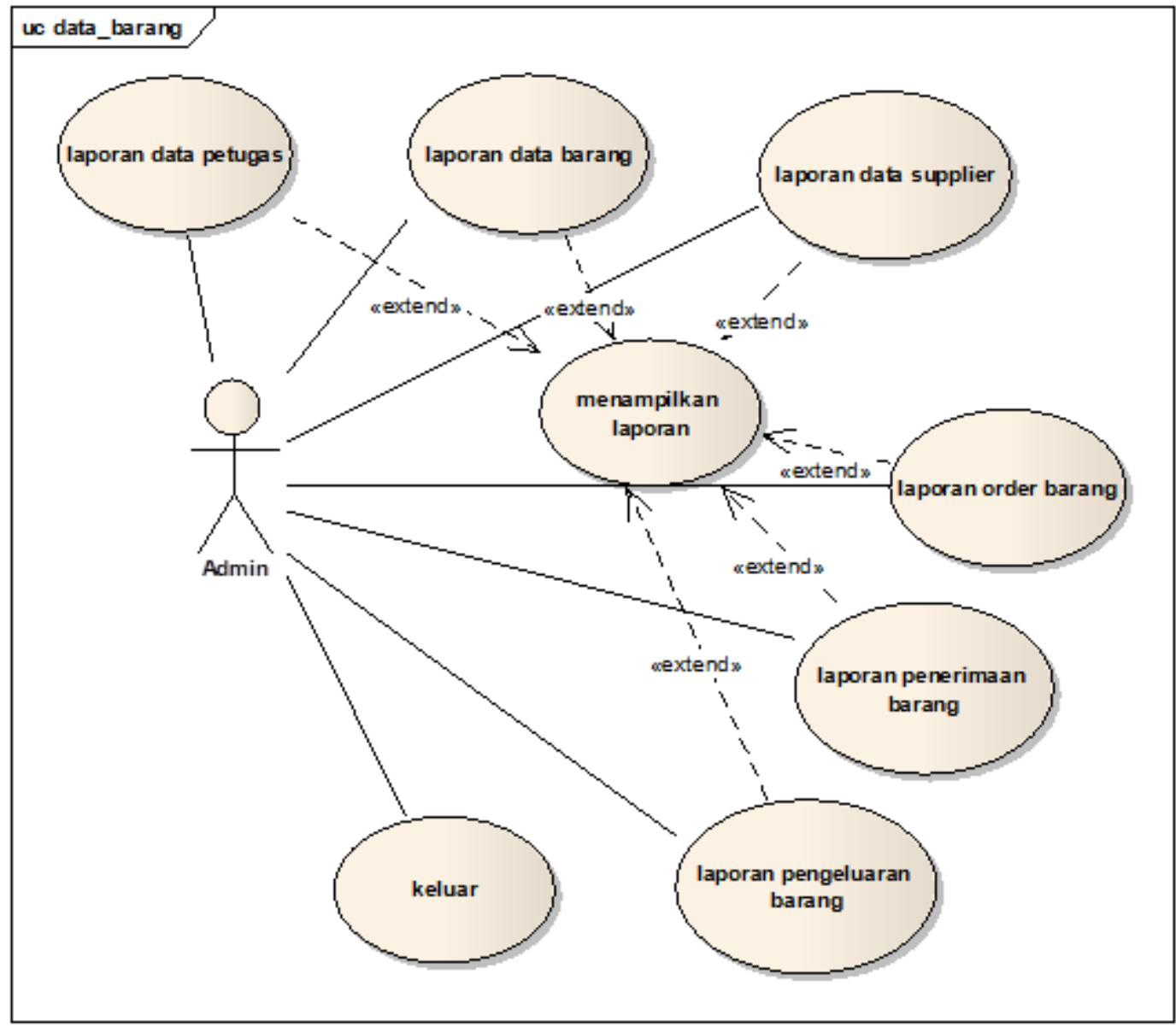

Gambar 9. Use Case Diagram Mengelola Laporan

3.3 Rancangan Tampilan

a. Tampilan Login

Pada tampilan login digunakan untuk petugas bagian gudang masuk pada menu utama untuk mengelola data persediaan barang.

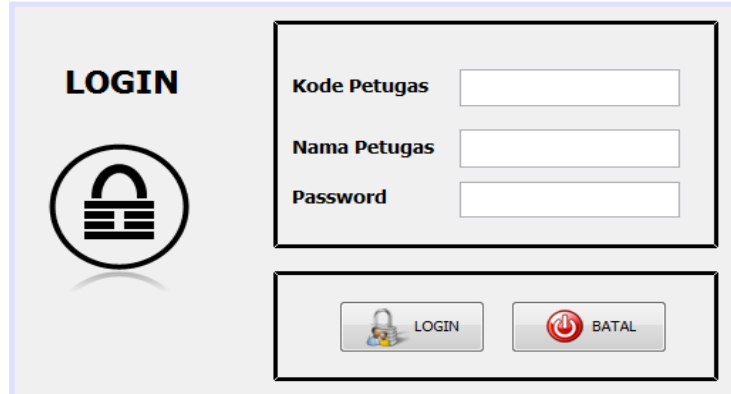

b. Tampilan Menu Utama

Gambar 10. Tampilan Login

Pada tampilan menu utama untuk mengelola atau menampilkan semua form yang terdapat pada sistem informasi persediaan barang. 


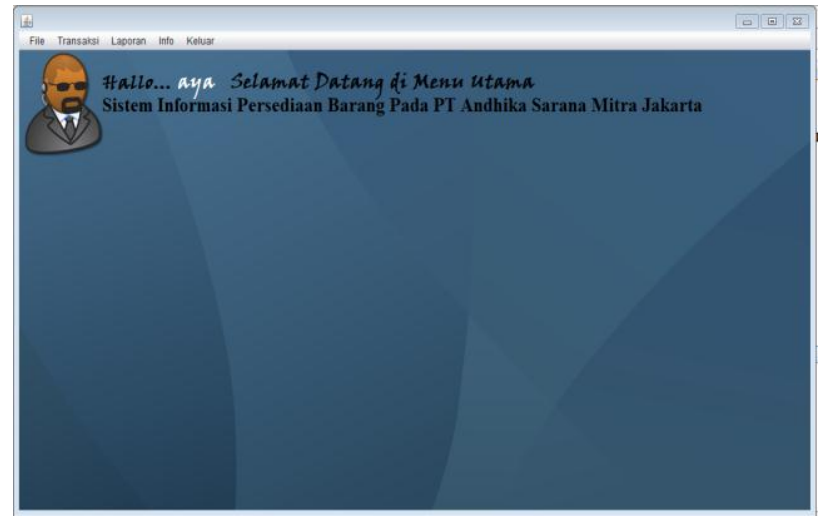

Gambar 11. Tampilan Menu Utama

c. Tampilan Form Petugas

Tampilan data petugas untuk bagian gudang melakukan pengelola data persediaan barang.

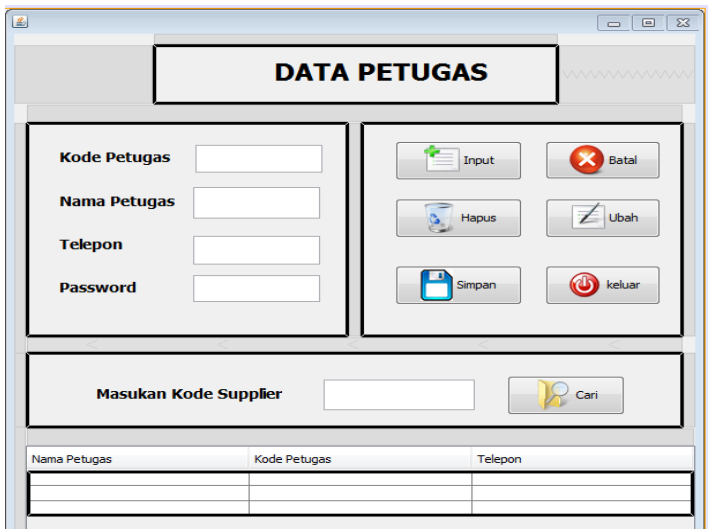

Gambar 12. Tampilan Form Petugas

d. Tampilan Form Data Barang

Form data barang untuk mengelola data barang yang baru masuk dan mengontrol jumlah persediaan barang.

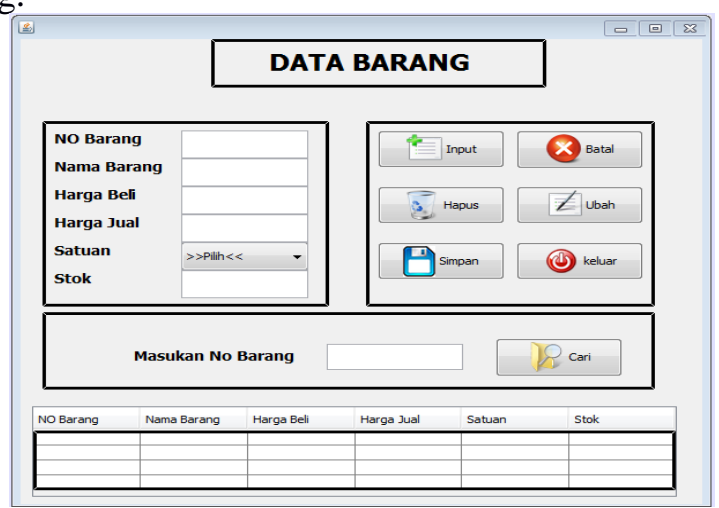

Gambar 13. Tampilan Form Data Barang

e. Tampilan Form Data Supplier

Pada form data supplier bagian gudang dapat mengelola data supplier seperti input, hapus maupun update data supplier. 


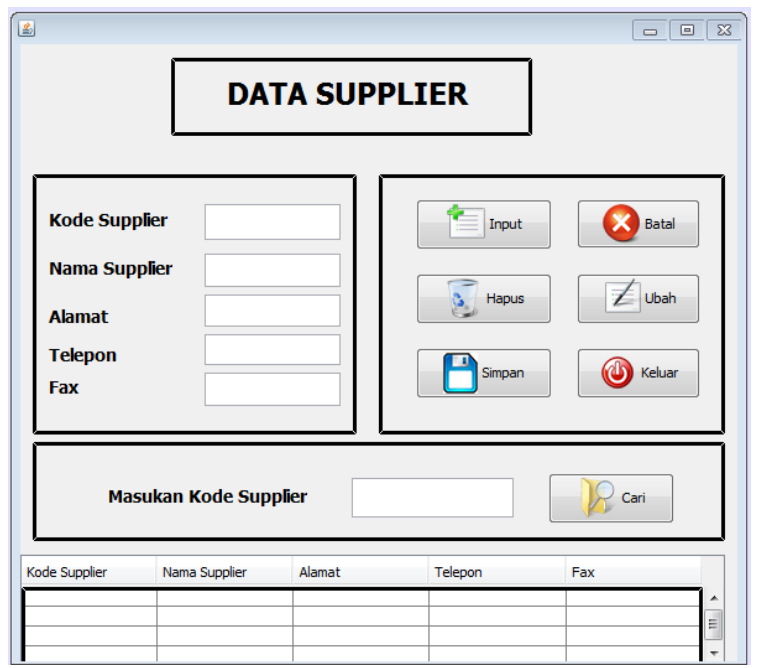

Gambar 14. Tampilan Form Data Supplier

d. Tampilan Form Data Penerimaan Barang

Pada form data penerimaan barang petugas bagian gudang dapat mengelola transaksi barang masuk dari supplier dan dapat mengetahui jumlah barang masuk beserta biaya barang tersebut.

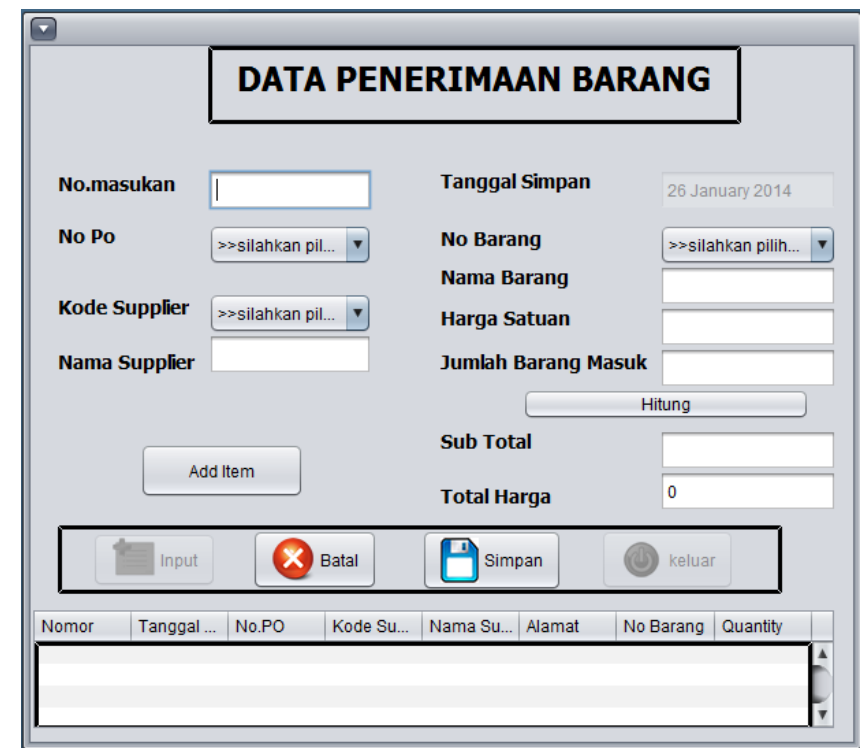

Gambar 15. Tampilan Form Data Penerimaan Barang

f. Tampilan Form Data Pengeluaran Barang

Pada form data pengeluaran barang digunakan oleh petugas gudang untuk mengelola transaksi pengeluaran barang yang dijual, sisa jumlah stok barang dan dapat mengetahui keuntungan yang didapat dari penjualan barang tersebut. 


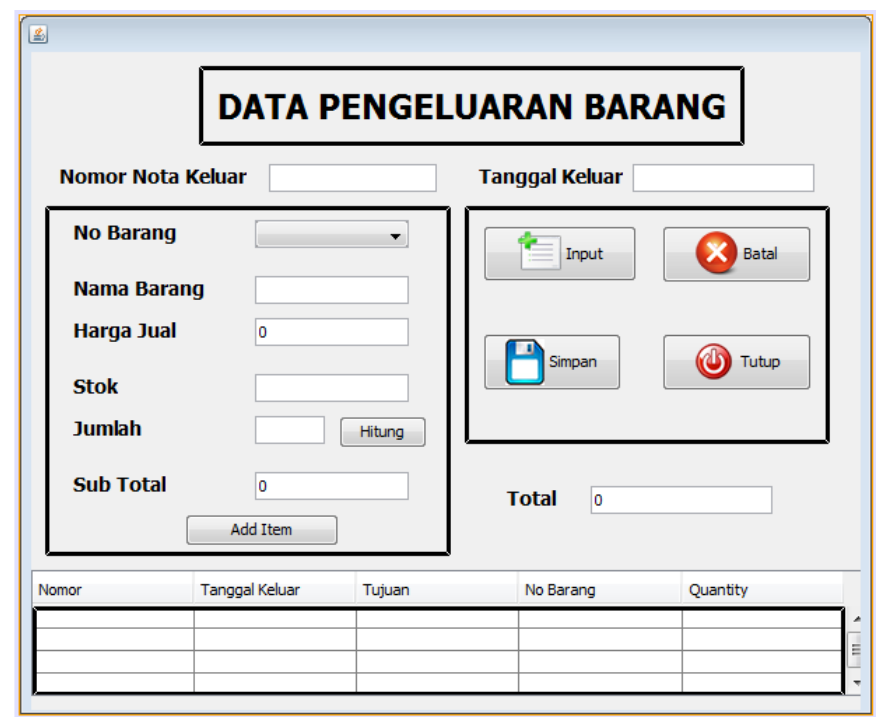

3.4 Testing

Gambar 16. Tampilan Form Data Pengeluaran Barang

Hasil Pengujian Blackbox Testing Form Login

\begin{tabular}{|c|c|c|c|c|c|}
\hline No. & Skenario Pengujian & Test Case & $\begin{array}{c}\text { Hasil yang } \\
\text { Diharapkan }\end{array}$ & $\begin{array}{c}\text { Hasil } \\
\text { Pengujian }\end{array}$ & Kesimpulan \\
\hline 1. & $\begin{array}{l}\text { Menggosongkan Data } \\
\text { Login. }\end{array}$ & $\begin{array}{l}\text { Kode Petugas } \\
\text { (Kosong) } \\
\text { Password } \\
\text { (kosong) }\end{array}$ & $\begin{array}{llr}: & \text { Sistem akan menolak } \\
\text { akses } & \text { login } \\
\text { : } & \text { menampilkan pesan } \\
\text { "Maaf, username anda } \\
\text { masih kosong" }\end{array}$ & $\begin{array}{l}\text { Sesuai } \\
\text { harapan }\end{array}$ & Valid \\
\hline 2. & $\begin{array}{lr}\text { Hanya Mengisi } & \text { data } \\
\text { kode } & \text { dan } \\
\text { mengosongkan data } & \text { dassword, } \\
\text { palu } \\
\text { langsung mengklik } \\
\text { tombol "Login" }\end{array}$ & $\begin{array}{l}\text { Kode Petugas } \\
001 \\
\text { Password } \\
\text { (kosong) }\end{array}$ & $\begin{array}{llr}: & \text { Sistem akan } & \text { menolak } \\
\text { akses } & \text { login } \\
: & \text { menampilkan pesan } \\
& \text { "Maaf, password anda } \\
& \text { masih kosong" }\end{array}$ & $\begin{array}{l}\text { Sesuai } \\
\text { harapan }\end{array}$ & Valid \\
\hline 3. & $\begin{array}{lr}\text { Hanya Mengisi } & \text { data } \\
\text { password } & \text { dan } \\
\text { mengosongkan data } \\
\text { kode petugas, Lalu } \\
\text { langsung mengklik } \\
\text { tombol "Login" }\end{array}$ & $\begin{array}{l}\text { Kode Petugas } \\
\text { (kosong) } \\
\text { Password: } \\
123456\end{array}$ & $\begin{array}{lr}\text { Sistem akan } & \text { menolak } \\
\text { akses } & \text { login } \\
\text { menampilkan } & \text { pesan } \\
\text { "Maaf, kode } & \text { anda } \\
\text { masih kosong" } & \end{array}$ & $\begin{array}{l}\text { Sesuai } \\
\text { harapan }\end{array}$ & Valid \\
\hline 4. & $\begin{array}{l}\text { Menginput data login } \\
\text { yang benar, Lalu } \\
\text { langsung mengklik } \\
\text { tombol "Login" }\end{array}$ & $\begin{array}{l}\text { Username } \\
\text { Lukman } \\
\text { Password : } \\
123456\end{array}$ & $\begin{array}{l}\text { Sistem menerima akses } \\
\text { login dan kemudian } \\
\text { langsung menampilkan } \\
\text { form halaman utama }\end{array}$ & $\begin{array}{l}\text { Sesuai } \\
\text { harapan }\end{array}$ & Valid \\
\hline
\end{tabular}

\section{KESIMPULAN}

Dari hasil pembuatan aplikasi dan hasil riset di PT Andhika Sarana Mitra maka penulis menyimpulkan kesimpulan diantaranya:

1. Aplikasi sistem informasi persediaan barang ini dapat mempermudah dan mempercepat kinerja petugas bagian gudang.

2. Dengan adanya aplikasi ini perusahaan dapat melihat persediaan barang dan dapat lebih teratur dalam proses transaksi persediaan barang.

3. Kegiatan pencatatan transaksi pemesanan barang, penerimaan barang dan pengeluaran barang sudah memakai komputer tetapi masih menggunakan Microsoft Excel sebagai alat hitung dan memproses data, sehingga bisa mengakibatkan terjadinya kesalahan dalam pencatatan penerimaan dan pengeluaran barang, dalam setiap pengerjaannya masih kurang efektif dan efisien. 
4. Waktu proses menjadi relatif lebih cepat.

\section{SARAN}

Berdasarkan kesimpulan yang di paparkan dalam pembuatan aplikasi sistem informasi persediaan barang ini, penulis memberikan saran yang nantinya bermanfaat untuk alternatif pemikiran dan pengembangan kedepannya yaitu:

1. Diperlukan penyediaan perangkat lunak (software) dan perangkat keras (hardware) yang lebih baik kemampuannya untuk lebih meningkatkan hasil pengolahan data.

2. Mengingat pentingnya data-data, maka harus diperhatikan dalam hal penyimpanan data melalui backup data dan perlunya password untuk menjaga keamanan data agar tidak sembarang orang dapat mengakses data tersebut.

3. Perlu diadakan pengembangan sistem informasi persediaan barang berbasis komputer yang dapat mengelola dan mengolah data lebih akurat dan untuk menghasilkan informasi yang berhubungan dengan persediaan serta untuk mengoptimalkan prosedur kerja.

\section{UCAPAN TERIMA KASIH}

Penulis menyadari bahwa tanpa bimbingan dan dorongan dari semua pihak, maka penelitian ini tidak akan berjalan lancar. Oleh karena itu pada kesempatan ini, maka izinkanlah penulis menyampaikan ucapan terima kasih kepada:

1. Pimpinan PT Andhika Sarana Mitra Jakarta serta segenap karyawan yang bertugas.

2. Tenaga Pendidik dan Kependidikan STMIK YMI Tegal.

3. Kedua orangtua dan semuanya yang selalu memberikan motivasi.

\section{DAFTAR PUSTAKA}

[1] Aryo Nugroho. 2008. Belajar Sendiri Mengimplementasikan SQL Server 2008. Elex Media Komputindo.

[2] Junaidi, Retno, Khusnul. 2015. Rancang Bangun Sistem Penerimaan dan Pengeluaran Barang Menggunakan Java Aplikasi. KNSI 2015: 842-845.

[3] Rosdiana, Eva, Mellly. 2015. Sistem Informasi Persediaan dan Penjualan Barang Berbasis Web Pada Koperasi Kosma 15. KNSI 2015: 915-920.

[4] Ni Ketut Dewi Ari Jayanti. 2015. Sistem Informasi Persediaan Barang Menggunakan Model Reorder Point. Eksplora Informatika, 5(1): 85-96.

[5] Budi, Dini, Partono. 2012. Perancangan Sistem Informasi Inventory Barang Di Bank Sampah Garut. Jurnal Algoritma, 9(32): 1-12.

[6] Rusdah. 2011. Analisa Dan Perancangan Sistem Persediaan Obat: Studi Kasus Puskesmas Kecamatan Kebon Jeruk. Jurnal Telematika, 3(2): 17:24.

[7] Munawar. 2007. Pemodelan Visual Dengan UML. Graha Ilmu.

[8] Raharjo Budi, Imam Heryanto, Arif Haryono. 2010. Tuntunan Pemrograman Java Untuk Hanphone Edisi Revisi. Bandung: Informatika. 